\title{
Spatial and temporal variations in the nutritional composition of some seaweeds from the Red Sea, Egypt
}

\author{
Islam M. El-Manawy ${ }^{1 *}$, Mohamed Z. Nassar ${ }^{2}$ and Sarah H. Rashedy ${ }^{2}$ \\ ${ }^{1}$ Faculty of Science, Botany Department, Suez Canal University \\ ${ }^{2}$ National Institute of Oceanography and Fisheries
}

\begin{abstract}
:
Spatial and seasonal variations in the nutritional composition of the dominant seaweed species were assessed at three sites during 2017 from Hurghada and Safaga of the Red Sea coast. Results showed that six species were dominant and had the highest coverage during the study period. The proximate composition of these seaweeds showed a significant difference among sites and seasons and the correlation with the environmental parameters were established. Fibers content of the tested seaweeds were higher and varied among the sites and seasons (26.5-53.5 \% dry wt.). Available carbohydrates levels (8.4-25.3\% dry wt.) were positively correlated with seawater temperature, $\mathrm{pH}$ value and salinity. Total soluble protein of these seaweeds was varied significantly between seasons (3.2-8.3\% dry wt.) with the highest values in winter while there is no significant difference between the sites. The protein levels were positively correlated with dissolved nitrate and silicate but negatively correlated with water temperature. Total lipid content of the tested seaweeds was varied between $1.1 \%$ dry wt. in winter and $0.6 \%$ dry wt. in spring. It was significantly correlated with nitrite and $\mathrm{pH}$ value, while ash content was not varied among the sites and seasons.
\end{abstract}

Keywords: Red Sea seaweeds, Spatial and seasonal variations, Nutritional composition, Environmental parameters.

\section{Introduction}

Seaweeds are considered as a highly nutritive food having proteins, fibers, vitamins, minerals and essential fatty acids (Ortiz et al., 2006). They have traditionally used in Chinese, Japanese, and Korean diet since ancient times (Dawczynski et al., 2007). Besides, they could be eaten in raw salads, soups, cookies, meals, and condiments (Aguilera-Morales et al., 2005). However, they contain $80-90 \%$ water and their dry weight basis contains $50 \%$ carbohydrates, 1 $3 \%$ lipids and 7-38\% minerals. Their protein contents are highly variable (10 47\%) with high proportions of essential amino acids (García-Casal $\boldsymbol{e t ~ a l . , ~ 2 0 0 7 ) . ~}$ 
Macroalgae respond to various climatic and physicochemical factors. Their survival, growth, and reproduction are depend on and vary with numerous key environmental variables such as temperature, salinity, hydrodynamics, wave exposure, nutrients, carbon dioxide and $\mathrm{pH}$ (Harley et al., 2012).

The nutritive value of seaweeds may vary since there is a strong correlation between biogeographically conditions and composition of mainly fatty acids, amino acids and minerals (Goecke et al., 2010). The composition of the same seaweed may differ depending on the season of the year, growth stage, part of the seaweed harvested, geographic location, etc. Thus, to assure the nutritional value of seaweeds, they need to be evaluated before used them as supplements (Kim, 2012).

Although there have been many studies on the nutritional composition of the Red Sea macroalgae (El-Manawy, 2008; Osman et al., 2011 and Moubayed et al., 2017), studies which related to seasonal and spatial changes in the nutritional composition are still scarce. Studies involving seasonality are also important for applied researches because it is important to know the best period to harvest algae for the nutritional composition. Therefore, this study is carried out to:

- Define the algae that could be used as a sustainable resource all the year round and determine their environmental regulating conditions.

- Assessing the spatial and seasonal variations in nutritional composition of some common seaweed of the Red Sea coast.

\section{Materials and Methods}

\section{Area of study and time of collection}

A preliminary visual survey on the Egyptian Red Sea coast, using snorkeling led to selection of three sites which represent different hydrographic habitats along the north western coast of the Red sea (Figure 1). The selected sites are: site I is located in front of the National Institute of oceanography and Fisheries (NIOF) between latitudes $27^{\circ} 17^{\prime} 13^{\prime \prime} \mathrm{N}$ and longitudes $33^{\circ} 46^{\prime} 21^{\prime \prime} \mathrm{E}$, 
site II (Mangrove) is located about $17 \mathrm{~km}$ south of Safaga in the mangrove forest. It lies between latitudes $26^{\circ} 36^{\prime} 59^{\prime \prime} \mathrm{N}$ and longitudes $34^{\circ} 00^{\prime} 41^{\prime \prime} \mathrm{E}$ and site III (Kalawy) which is located between latitudes $26^{\circ} 06^{`} 12^{\prime \prime} \mathrm{N}$ and longitudes $34^{\circ} 17^{`}$ $08^{\prime \prime}$ E, close to Magic Life Kalawy Resort at about $50 \mathrm{~km}$ south of Safaga City. Seasonally, the collection of samples was carried out to the different three sites during winter (February), spring (May), summer (August) and autumn (November) in 2017.

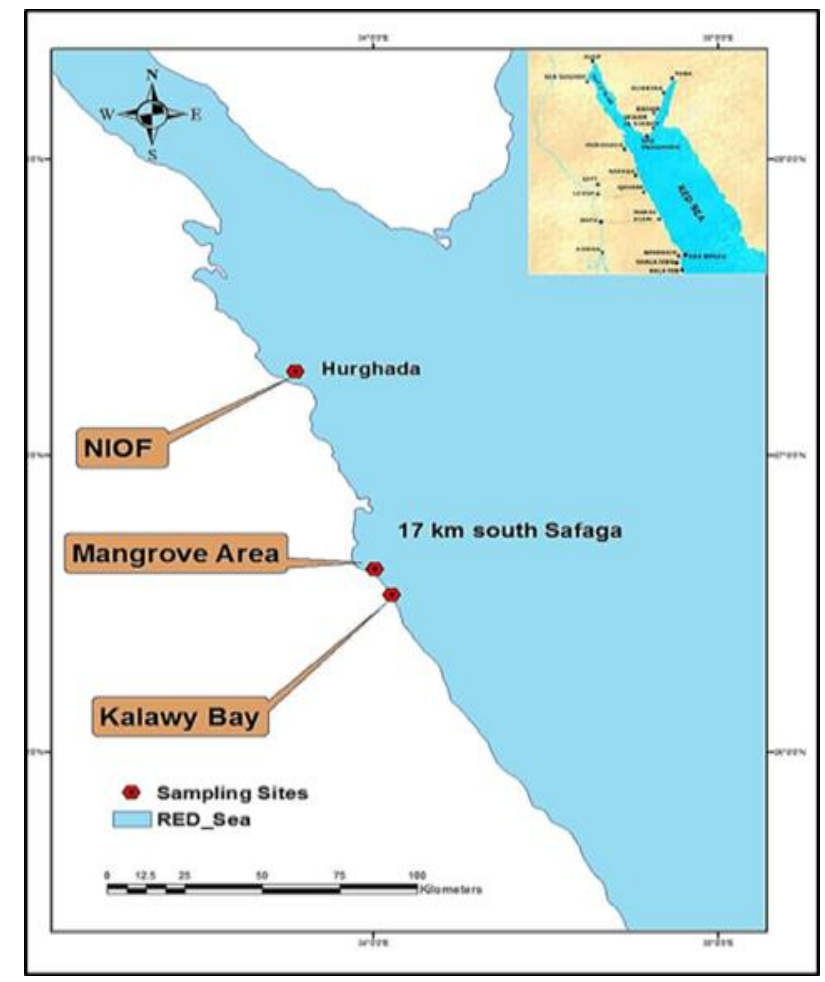

Figure 1: Positions of the sampling sites 


\section{Analysis of physico-chemical parameters}

Water temperature, $\mathrm{pH}$ value, salinity, total dissolved solids (TDS) and dissolved oxygen (DO) were determined from the average of three readings at each site by the multiparameter instrument (YSI ProODO Instrument). Turbidity was measured by turbidity-meter (LaMotte 2020e). The nutrient salts (dissolved inorganic nitrite $\left(\mathrm{NO}_{2}\right)$, dissolved nitrate $\left(\mathrm{NO}_{3}\right)$, dissolved ammonium $\left(\mathrm{NH}_{4}\right)$, dissolved inorganic phosphate $\left(\mathrm{PO}_{4}\right)$ and reactive silicate $\left.\left(\mathrm{SiO}_{4}\right)\right)$ were determined spectrophotometrically in $\mu \mathrm{M}$ according to the methods described by APHA (2005).

\section{Community composition and cover percent of seaweeds}

To characterize the spatial changes in the algal composition, three $20 \mathrm{~m}$ permanent line-transects were set in each site. At each transect, three $1-\mathrm{m}^{2}$ quadrates were randomly laid, as a replica. Macroalgal vegetation was described quantitatively through measuring percentage cover of each species inside the quadrate (Russell and Fielding, 1981). Temporal changes in macroalgal cover were determined during calendar given above. All works were carried out by snorkeling.

\section{Macroalgal selection, collection and preparation.}

Macroalgae that represented the highest cover during the year of the study and found at the three chosen sites were selected to the nutritional composition. The algae were identified by morphological characters like the pigment, structure of the vegetative thallus long with reproductive and other characters using taxonomic references (Aleem, 1978; Coppejans and Beeckman, 1990 and Sahoo, 2001). Healthy algae were harvested manually and washed thoroughly in seawater to remove adhering detritus matters. Fresh materials were thoroughly washed again with freshwater to remove excess salt. Cleaned algae materials were shade dried under an air jet to prevent photolysis and thermal degradation. The 
completely dried material was weighed and ground coarsely in a mechanical grinder and then stored in sealed plastic pages.

\section{Determination of nutritional composition of the selected algal samples}

Moisture and ash were measured by AOAC (1995), total soluble proteins by Lowry $\boldsymbol{e}$ al. (1951), total lipids by AOAC (2000), crude fibers by AOAC (1990) and available carbohydrate was estimated by subtraction of the sum of ash, protein, lipid, moisture and crude fiber values from 100 (Márcia de Pádua et al., 2004). All measurements were recorded as the percentage dry weight.

\section{Statistical analysis}

The spatial and temporal variability are illustrated by Boxplots graph. The statistical significance of these variations is illustrated by one-way ANOVA and Fisher's grouping test. Pearson correlation coefficients were applied in the present data. All statistical tests were performed using Minitab ${ }^{\circledR}$ (Version 16) software.

\section{Results}

\section{Community composition and cover percent of seaweeds}

Thirty-six species of macroalgae were collected and identified from the studied sites. About $36.1 \%$ of these algae (13 species) belong to phylum Chlorophyta, 36.1\% (13 species) belongs to phylum Phaeophyta and $27.8 \%$ (10 species) belongs to phylum Rhodophyta. Cover percent of each species at the three sites was measured in four seasons as presented in Table 1. 
Table 1: Average annual cover (\%) of seaweeds at the different three sites.

\begin{tabular}{|c|c|c|c|}
\hline Species & Site I & Site II & Site III \\
\hline \multicolumn{4}{|l|}{ Chlorophyta } \\
\hline Boergesenia forbesii (Harvey) Feldmann & 2 & 0 & 0 \\
\hline$\star$ Caulerpa racemosa var. gracilis (Zanardini)Weber-van Bosse & 8 & 0 & 11 \\
\hline Caulerpa serrulata (Forsskal) J. Agardh & 2 & 4 & 0 \\
\hline Codium arabicum Kützing & 2 & 0 & 0 \\
\hline Codium decorticatum (Woodward) Howe & 1 & 0 & 0 \\
\hline Codium tomentosum Stackhouse & 1 & 0 & 0 \\
\hline Codium dwarkense Børgesen & 1 & 0 & 0 \\
\hline Dictyosphaeria cavernosa (Forsskal) Børgesen & 2 & 0 & 1 \\
\hline Valonia aegagropila C.Agardh & 6 & 0 & 1 \\
\hline Halimeda discoidea Decaisne & 0 & 0 & 3 \\
\hline Halimeda macroloba Decaisne & 1 & 0 & 2 \\
\hline Halimeda opuntia (Linnaeus) Lamouroux & 0 & 14 & 0 \\
\hline Halimeda tuna (Ellis et Solander) & 4 & 0 & 3 \\
\hline \multicolumn{4}{|l|}{ Phaeophyta } \\
\hline Colpomenia sinuosa Derbes et Solier & 2 & 3 & 4 \\
\hline Dictyota dichotoma (Hudson) Lamouroux & 5 & 2 & 10 \\
\hline Hydroclathrus clathratus (C. Agardh) Howe & 2 & 1 & 6 \\
\hline$\star$ Padina boergesenii Alender\& Kraft & 13 & 15 & 8 \\
\hline$\star$ Polycladia myrica (Gmelin) C. Agardh & 13 & 23 & 20 \\
\hline Cystoseira trinodis (Forsskal)C. Agardh & 2 & 10 & 6 \\
\hline$\star$ Hormophysa cuneiformis (Gmelin) Silva & 11 & 21 & 17 \\
\hline Sargassum acinacifolium Setechell\& Gardner & 0 & 5 & 0 \\
\hline$\star$ Sargassum aquifolium (Turner) C. Agardh & 10 & 22 & 28 \\
\hline Sargassum Latifolium (Turner) C. Agardh & 3 & 5 & 0 \\
\hline Sargassum polycystum C. Agardh & 1 & 0 & 0 \\
\hline Sargassum subrepandum (Forsskal) C. Agardh & 1 & 0 & 0 \\
\hline Turbinaria turbinate (Linnaeus) Kuntzing & 3 & 0 & 0 \\
\hline \multicolumn{4}{|l|}{ Rhodophyta } \\
\hline Chondria seticulosa (Forskal) C. Agardh & 0 & 0 & 5 \\
\hline Chondria collinsiana Howe & 1 & 0 & 0 \\
\hline$\star$ Digenea simplex (Wulfen) C. Agardh & 15 & 12 & 0 \\
\hline Amphiroaanceps(Lamarck) Decaisne & 11 & 0 & 0 \\
\hline Actinotrichia fragilis (Forsskal) Børgesen & 2 & 0 & 0 \\
\hline Galaxaura rugosa (Ellis \&Solander) Lamouroux & 1 & 0 & 0 \\
\hline Laurencia papillosa (C. Agardh) Greville & 1 & 0 & 3 \\
\hline Laurencia obtuse (Forsskal) Greville & 9 & 0 & 0 \\
\hline Ganonema farinosum (Lamouroux) Fan\&Yung Wang & 3 & 1 & 4 \\
\hline Gracilaria arcuata Zanardini & 3 & 0 & 6 \\
\hline
\end{tabular}

$\star$ Seaweeds that represent the highest cover during the year of study

Egyptian J. of Phycol. Vol. 20, 2019

- 34 - 


\section{Selection of seaweeds for biochemical studies.}

From the results in Table 1, the highest cover of seaweed species during the study period were Caulerpa racemosa var. gracilis from Chlorophyta, Padina boergesenii, Polycladia myrica, Hormophysa cuneiformis and Sargassum aquifolium from Phaeophyta and Digenea simplex from Rhodophyta. Thus, they were selected to study the spatial and temporal variations of their nutritional composition.

\section{Nutritional composition of the investigated seaweeds}

The nutritional contents of the six investigated seaweeds are shown in Table 2. The major constituents of these algae were ash (24.8-44.2\% dry wt.) and crude fibers (30.3-38.9\% dry wt.), medium values of available carbohydrates (8.4-25.3\% dry wt.), moisture (4.2-8.7 \% dry wt.) and protein (4.6-6.5\% dry wt.), while showed low values of total lipids (0.7-4.2\% dry wt.).

Table 2: Nutritional composition (\% dry wt.) of the investigated seaweeds

\begin{tabular}{|l|cccccc|}
\hline Species & $\begin{array}{c}\text { Available } \\
\text { Carbohydrate }\end{array}$ & Protein & Lipid & Moisture & Ash & Fiber \\
\hline C. racemosa & $15.2 \pm 1 \mathrm{~B}$ & $4.6 \pm 0.7 \mathrm{D}$ & $4.2 \pm 0.9 \mathrm{~A}$ & $5.7 \pm 1.2 \mathrm{~B}$ & $27.9 \pm 3.6 \mathrm{C}$ & $38.9 \pm 5.3 \mathrm{~A}$ \\
D. simplex & $25.3 \pm 1.5 \mathrm{~A}$ & $5.1 \pm 0.7 \mathrm{CD}$ & $0.9 \pm 0.4 \mathrm{CD}$ & $4.2 \pm 1.7 \mathrm{C}$ & $24.8 \pm 3.9 \mathrm{D}$ & $30.3 \pm 5.4 \mathrm{C}$ \\
H. cuneiformis & $16.7 \pm 1.4 \mathrm{~B}$ & $6.2 \pm 1.5 \mathrm{AB}$ & $0.7 \pm 0.3 \mathrm{D}$ & $8.3 \pm 1.9 \mathrm{~A}$ & $30.2 \pm 2.1 \mathrm{~B}$ & $33.8 \pm 3.8 \mathrm{~B}$ \\
$\boldsymbol{P}$. boergesenii & $8.4 \pm 4.9 \mathrm{C}$ & $4.7 \pm 0.8 \mathrm{D}$ & $1.3 \pm 0.1 \mathrm{BC}$ & $6.1 \pm 2.1 \mathrm{~B}$ & $44.2 \pm 5.3 \mathrm{~A}$ & $34.2 \pm 5.4 \mathrm{~B}$ \\
$\boldsymbol{P}$. myrica & $14.4 \pm 0.6 \mathrm{~B}$ & $6.5 \pm 1.9 \mathrm{~A}$ & $1.0 \pm 0.4 \mathrm{CD}$ & $8.1 \pm 1.7 \mathrm{~A}$ & $30.1 \pm 2.7 \mathrm{~B}$ & $37.1 \pm 3.4 \mathrm{~A}$ \\
S. aquifolium & $13.1 \pm 0.4 \mathrm{~B}$ & $5.8 \pm 1.4 \mathrm{BC}$ & $1.4 \pm 0.5 \mathrm{~B}$ & $8.7 \pm 0.9 \mathrm{~A}$ & $30.6 \pm 4.1 \mathrm{~B}$ & $37.8 \pm 8.2 \mathrm{~A}$ \\
\hline
\end{tabular}

Values are expressed as annual average \pm standard deviation. Different letters indicate a significant difference at the level of $\mathbf{p} \leq \mathbf{0 . 0 5}$ 


\section{Spatial and temporal variations in nutritional composition of the selected seaweeds.}

\section{a. Available carbohydrate}

Spatial variation: Selected seaweeds at site I and II had the highest available carbohydrate content ranged from 8 to $25.5 \%$ dry wt., while seaweeds at site III was characterized by low content of carbohydrate than other sites with a range of 12.3 to $17.5 \%$ dry wt. as shown by box plots (Fig. 2a); the available carbohydrate of the studied seaweeds showed a significant differences among the sites. Grouping of sites based on total carbohydrate content of the selected seaweeds indicated a similarity between site I and II, while site III was differed significantly from these two sites.

Temporal variations: Box plots (Fig. 2b) indicate that summer had the highest median (15.2\% dry wt.) followed by autumn (14.6\% dry wt.) and the lowest in spring and winter (14\% dry wt.). According to the length of box, summer and autumn had the highest variability while lowest variability in spring. In general, total carbohydrates of the tested seaweeds were varied among seasons and this is approved by ANOVA which showed highly significant differences between seasons.

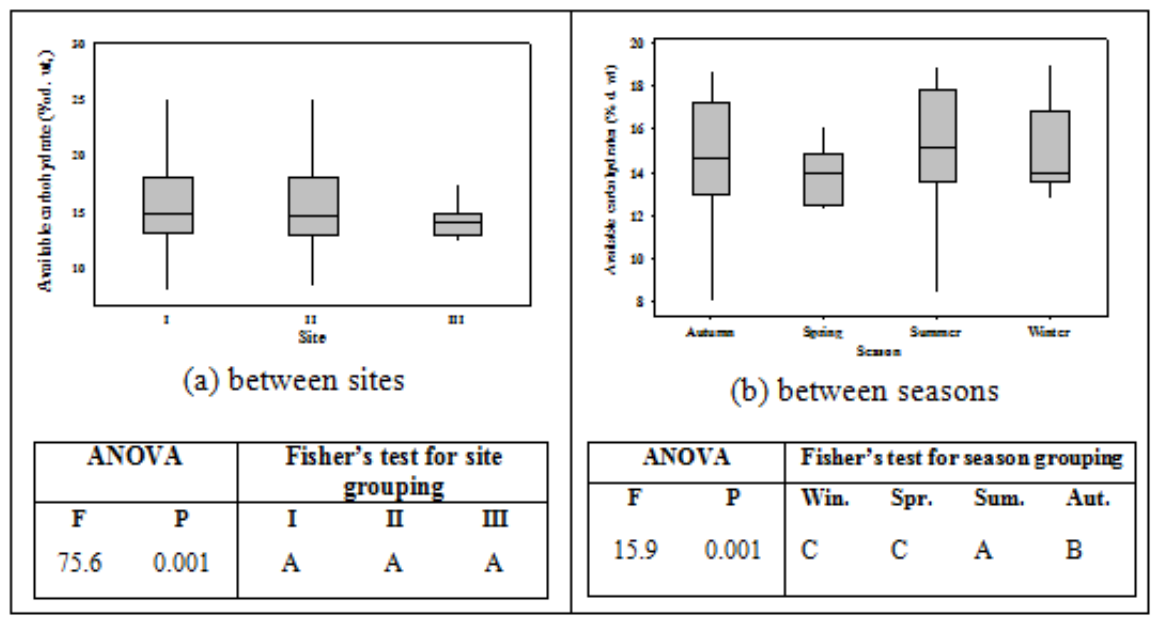

Fig. 2: Spatial and temporal variations in available carbohydrate (\% dry wt.) of the tested seaweeds. 


\section{b. Total soluble protein}

Spatial variation: Boxplots of spatial variation in the total soluble proteins of the investigated algae (Fig. 3a) showed that seaweeds at site II had the highest median $(6.3 \%)$, while seaweeds at other two sites had the same median (5.3\%). There are two outliers at site I, one of them was $10.3 \%$ for the brown seaweed $P$. myrica and the other was $9.8 \%$ for other brown seaweed $H$. cuneiformis. As shown by box plots, the ANOVA results and grouping test (Fig. 3a) indicate no significant difference between sites.

Temporal variations: Box plots showed that winter had both the highest median of $6.7 \%$ and variability. At the same time, protein content of the tested seaweeds in winter ranged from $5.1 \%$ to $10.3 \%$ and a long whiskers at the top of box indicated that high content of protein were more fluctuated in winter. In contrast, spring had both the lowest median of $4.2 \%$ and variability. One outlier during spring, it was $6.5 \%$ for $H$. cuneiformis at site II; this value can't be avoided from the sample (Fig. 3b). In brief, the total soluble protein of the tested algae showed large variations between seasons and this is approved by one way ANOVA (Fig. 3b).

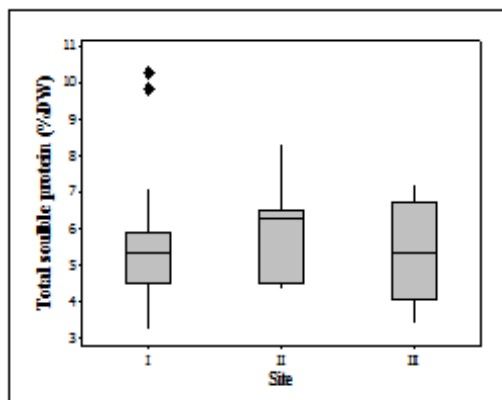

(a) between sites

\begin{tabular}{|cc|ccc|}
\hline \multicolumn{2}{|c|}{ ANOVA } & \multicolumn{4}{|c|}{$\begin{array}{c}\text { Fisher's test for site } \\
\text { grouping }\end{array}$} \\
\hline F & P & I & II & III \\
1.95 & 0.145 & A & A & A \\
\hline
\end{tabular}

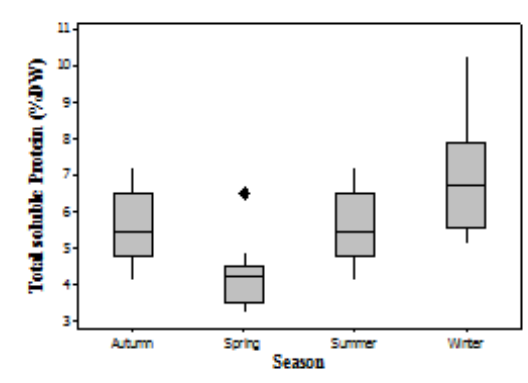

(b) between seasons

\begin{tabular}{|cc|cccc|}
\hline \multicolumn{2}{|c|}{ ANOVA } & \multicolumn{4}{|c|}{$\begin{array}{c}\text { Fisher's test for season } \\
\text { grouping }\end{array}$} \\
\hline F & P & Win. & Spr. & Sum. & Aut. \\
45.2 & 0.000 & A & C & B & B \\
\hline
\end{tabular}

Fig. 3: Spatial and temporal variations in total soluble proteins (\% dry wt.) of the tested seaweeds. 


\section{c. Total lipids}

Spatial variation: As shown in Fig. 4a, site I had both the highest median (1.3\%) and variability, while site II had both the lowest median $(0.74 \%$ dry wt.) and variability. At the same time the outliers of $4.5 \%$ dry wt. and $3.9 \%$ dry wt., for Caulerpa racemosa are distributed randomly at site III. Generally, the results of total lipids content of the selected seaweeds were fluctuated among sites and this is approved by the statistical analysis ANOVA which showed high significant variations between sites.

Temporal variations: Total lipid content of the tested seaweeds was varied between $1.1 \%$ dry wt. during winter and $0.6 \%$ dry wt. during spring. While in summer and autumn, seaweeds had the same median (0.89\% dry wt.) and highest variability. Boxplots showed slightly fluctuation among seasons. However, ANOVA results showed no significant difference among seasons (Fig. 4b).



Fig. 4: Spatial and temporal variations in total lipids (\% dry wt.) of the tested seaweeds. 


\section{d. Moisture content}

Spatial variation: Moisture content of the investigated algae was measured from 2.5 to $11 \%$ dry wt. at site I, $3.6-9.3 \%$ dry wt. at site II and 3.29.4\% dry wt. at site III (Fig. 5a). ANOVA results and grouping test (Fig. 5a) indicated no significant difference between sites.

Temporal variations: The highest median was $8.6 \%$ dry wt. during summer followed by autumn $8.5 \%$ dry wt., while the lowest median was $4.6 \%$ dry wt. during spring. Generally, ANOVA results showed that there are significant differences between seasons (Fig. 5b).

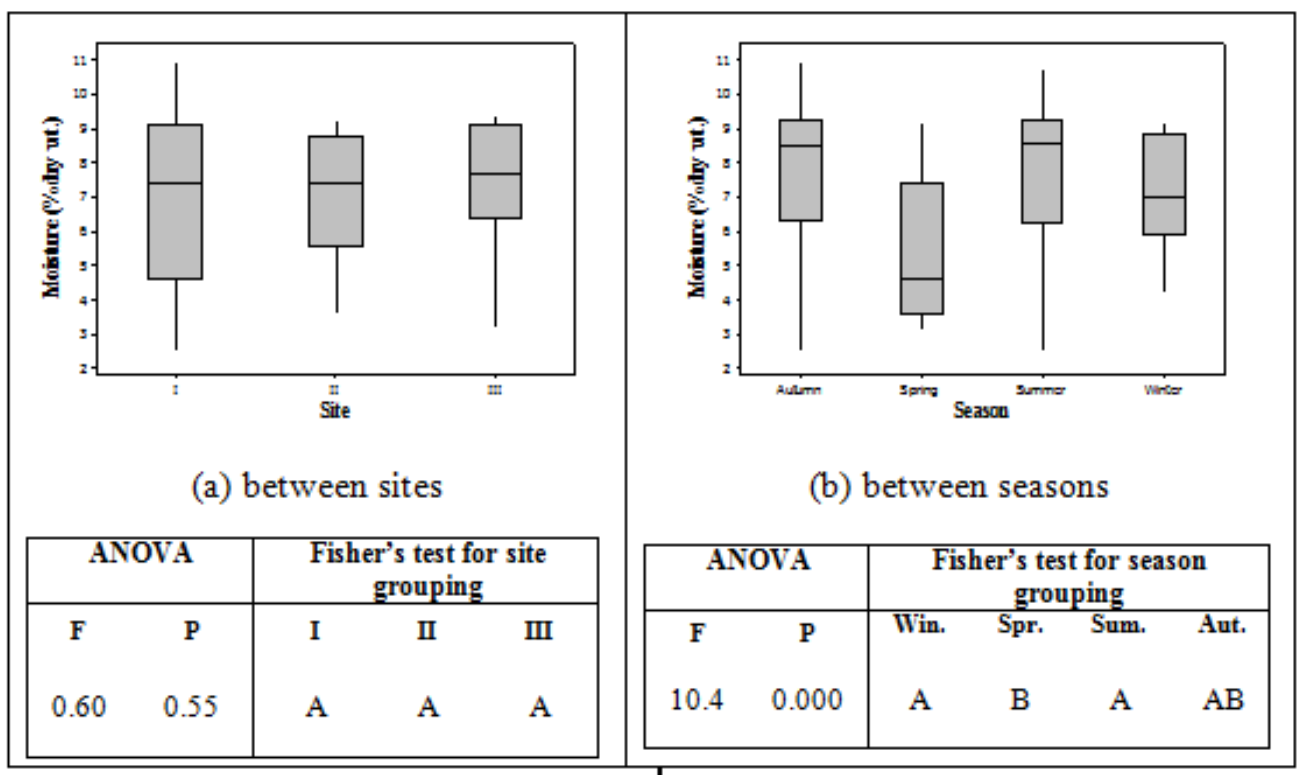

Fig. 5: Spatial and temporal variations in moisture content (\% dry wt.) of the tested seaweeds. 


\section{e. Ash content}

Spatial variation: Ash content of the tested algae ranged from 21.6 to $36.4 \%$ dry wt., at site I; $22.4-41.1 \%$ dry wt., at site II and $20.8-46.6 \%$ dry wt., at site III. It is worth to note that the medians in all sites were 30.9, 30.5 and $29 \%$ dry wt. respectively and the difference was less than $1.9 \%$. The fluctuation at site III was greater than the other sites (Fig. 6a). ANOVA and Fisher's grouping test showed no significant difference between sites. The letters associated with the values of grouping test were the same (A) and this proved that no significant difference between sites.

Temporal variations: The ash content of the selected seaweeds was closest of seasons where the highest median $31.2 \%$ dry wt. was recorded during summer followed by autumn ( $31 \%$ dry wt.). In winter and spring, the ash content was 29.9 and $29.3 \%$ dry wt. (Fig. 6b). Generally, ANOVA and Fisher's grouping test results showed no significant difference between seasons (Fig.6b).



Fig. 6: Spatial and temporal variations in ash content (\% dry wt.) of the tested seaweeds. 


\section{f. Total fibers}

Spatial variation: Fibers of the selected seaweeds ranged from 27.1 to $43.6 \%$ dry wt. at site I; $27.7-51.1 \%$ dry wt. at site II and $26.5-53.5 \%$ dry wt. at site III. In general, site II had the highest variability followed by site III (Fig. 7a). As shown by boxplots, the results of the total fibers of the studied seaweeds showed significant differences among sites.

Temporal variations: Boxplots (Fig. 7b) showed that, the highest median was $42.5 \%$ dry wt. during winter, while the lowest was $33.1 \%$ dry wt. during summer and autumn. Spring had the highest variability followed by summer; in contrast, winter had the lowest variability. There were two outliers during winter; one of them was small (29.4\%) belonging to the red seaweed $D$. simplex at site I and the other was large $(53.5 \%)$ for the brown seaweed $S$. aquifolium at site III. In general, fibers content of the tested seaweeds were varied highly among seasons. Grouping of seasons indicated a similarity between summer and autumn with a significant difference of winter and spring.

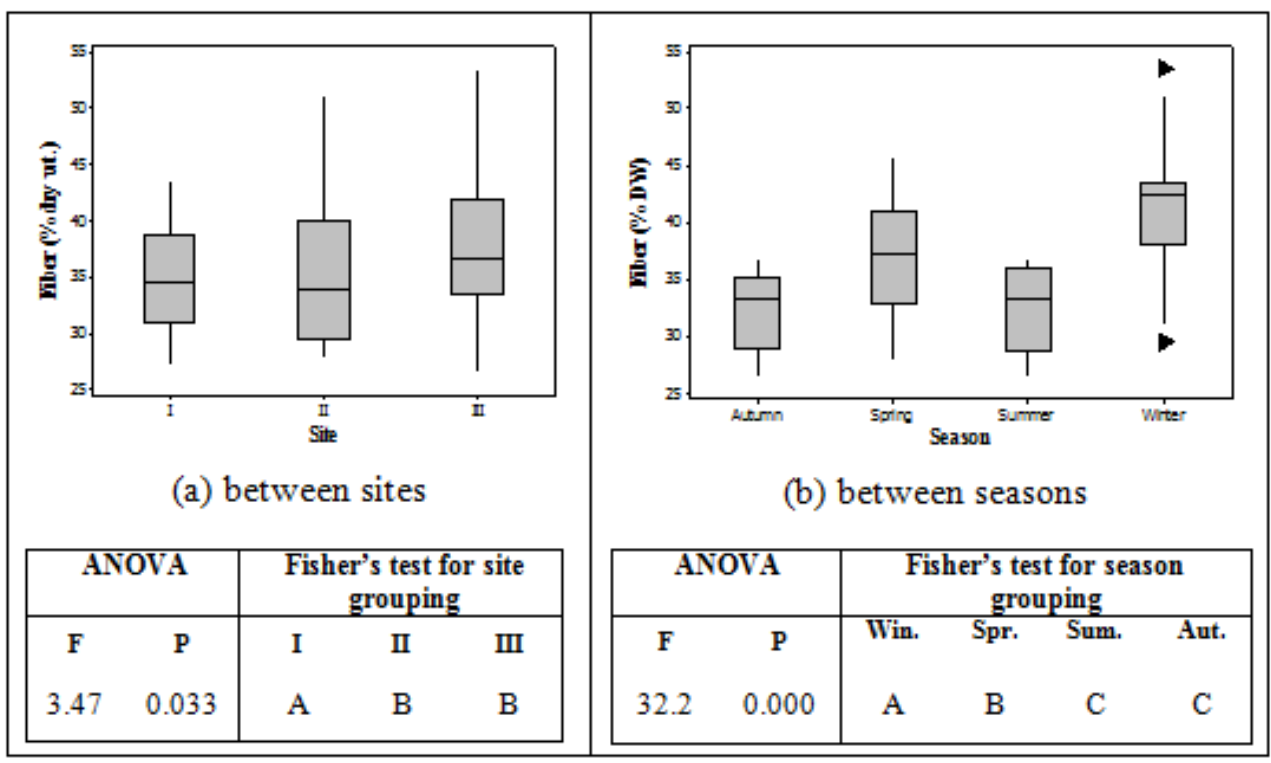

Fig. 7: Spatial and temporal variations in total fibers (\% dry wt.) of the tested seaweeds. 


\section{Correlations between nutritional compositions (\% dry wt.) of the investigated algae and environmental parameters}

Pearson correlations between nutritional compositions of seaweeds and the measured environmental parameters are presented in Table 3. Total carbohydrate (\% dry wt.) of the selected seaweeds showed a significant positive correlation with seawater temperature, $\mathrm{pH}$ value, salinity, nitrate, nitrite and reactive silicate $(\mathrm{r}=0.32,0.145,0.373,0.273,0.321$ and 0.204 respectively at $\mathrm{p}$ $<0.05$ ). Total soluble proteins ( $\%$ dry wt.) were moderately correlated with water temperature, nitrate and silicate ( $\mathrm{r}=-0.43,0.432$ and 0.403 , respectively, $\mathrm{p}<0.05$ ). Total lipids of the chosen seaweeds were significantly correlated with nitrite and $\mathrm{pH}$ value $(\mathrm{r}=0.342$ and $-0.24, \mathrm{p}<0.05)$. Ash content was positively correlated with water temperature and $\mathrm{pH}$ value $(\mathrm{r}=0.159$ and $167, \mathrm{p}<0.05)$, but it negatively correlated with nitrate and nitrite $(\mathrm{r}=-0.175$ and $-0.177, \mathrm{P}<0.05)$. Crude fibers $(\%$ dry wt.) of the tested seaweeds were strongly correlated with dissolved oxygen, nitrate and nitrite $(\mathrm{r}=0.396,0.201$ and 0.208 , respectively, $\mathrm{p}<0.05)$ but, they were negatively correlated with water temperature, $\mathrm{pH}$ value and reactive silicate $(\mathrm{r}=$ $0.306,-0.35,-0.315$ and -0.254 , respectively at $\mathrm{p}<0.05$ ). 
Table 3: The correlations between nutritional composition of the investigated algae and environmental parameters;

\begin{tabular}{|l|cccccc|}
\hline $\begin{array}{l}\text { Environmental } \\
\text { parameters }\end{array}$ & carbohydrate & Protein & lipid & Moisture & Ash & Fibers \\
\hline Temp. & $\mathbf{0 . 3 2}$ & $\mathbf{- 0 . 4 3}$ & -0.05 & -0.09 & $\mathbf{0 . 1 5 9}$ & $\mathbf{- 0 . 3 0 6}$ \\
pH & $\mathbf{0 . 1 4 5}$ & 0.128 & $\mathbf{- 0 . 2 4}$ & 0.111 & $\mathbf{0 . 1 6 7}$ & $\mathbf{- 0 . 3 5}$ \\
Salinity & $\mathbf{0 . 3 7 3}$ & $\mathbf{- 0 . 2 1}$ & 0.096 & 0.105 & -0.003 & -0.02 \\
Turbidity & 0.101 & 0.104 & -0.142 & -0.021 & 0.05 & -0.068 \\
DO & $\mathbf{- 0 . 1 5 4}$ & 0.156 & 0.011 & -0.124 & -0.108 & $\mathbf{0 . 3 9 6}$ \\
Nitrate & $\mathbf{0 . 2 7 3}$ & $\mathbf{0 . 4 3 2}$ & 0.239 & 0.089 & $\mathbf{- 0 . 1 7 5}$ & $\mathbf{0 . 2 0}$ \\
Nitrite & $\mathbf{0 . 3 2 1}$ & $\mathbf{0 . 3 1 1}$ & $\mathbf{0 . 3 4 2}$ & 0.102 & $\mathbf{- 0 . 1 7 7}$ & $\mathbf{0 . 2 0 8}$ \\
Ammonium & 0.128 & $\mathbf{0 . 3 1 2}$ & -0.070 & 0.106 & 0.035 & 0.088 \\
Phosphate & 0.094 & $\mathbf{0 . 2 6 4}$ & 0.073 & 0.035 & -0.08 & 0.129 \\
Silicate & $\mathbf{0 . 2 0 4}$ & $\mathbf{- 0 . 4 0 3}$ & 0.027 & -0.034 & 0.089 & $\mathbf{- 0 . 3 1 5}$ \\
\hline
\end{tabular}

Bolded correlation coefficients are significant at a p-level $\leq 0.05$.

\section{Discussion}

From the recorded 36 species in this study; six species were dominant and had the highest coverage during the study period. Also, they were found at the investigated three sites. Thus, they were selected to study the spatial and temporal variations of their nutritional composition. These species were Caulerpa racemosa var. gracilis (Chlorophyta), Padina boergesenii, Polycladia myrica, Hormophysa cuneiformis and Sargassum aquifolium (Phaeophyta) and Digenea simplex (Rhodophyta). Furthermore, previous studies confirmed that, these species were dominant at the different sites along the Red sea cost (El-Manawy, 2000 and 2001; El-Shoubaky and Kaiser, 2014; Kamal, 2014 and Ibraheem $\boldsymbol{e t}$ al., 2014). 
In the present study, available carbohydrates of the six selected seaweeds showed significant differences among sites. Seaweeds at site I and II had the highest carbohydrate content ranged from 8 to $25.5 \%$ dry wt. which may be due to the presence of the red seaweed $D$. simplex which contains the highest content of carbohydrates $(25.3 \pm 1.5 \%$ dry wt.). While, seaweeds at site III were characterized by the low content than other sites. This may attributed to the absence of the red seaweed D. simplex at this site. On the other hand, total carbohydrates of the tested seaweeds were varied among seasons. Summer had the highest median (15.2\% dry wt.), this season was marked by increased values of temperature, salinity and TDS, which has confirmed influence on carbohydrate synthesis (Marinho-Soriano et al., 2006). Also, the significant positive correlation found in this study between carbohydrate and temperature $(r=0.32)$ and the correlations with salinity were significant positive $(r=0.373)$. MarinhoSoriano et al., 2006 linked the carbohydrate synthesis to the periods of maximum growth, increased photosynthetic activity and a reduction in protein contents. In this study, the maximum available carbohydrate of the selected algae coincided with the cover maximum, suggesting a link between seaweeds growth and carbohydrate content.

The total soluble protein of the six studied seaweeds showed a small difference among sites. Seaweeds at Mangrove (site II) had the highest median (6.3\% dry wt.), while they recorded the same median at the other two sites $(5.3 \%$ dry wt.). Variation in the environmental conditions could explain the variation in the protein content at all sites such as temperature, salinity and nutrients (Banerjee et al., 2009). However, there were two outliers at site I; one of them was $10.3 \%$ dry wt. for the brown seaweed P. myrica and the other was $9.8 \%$ dry wt. for the other brown seaweed $H$. cuneiformis. Total soluble protein of the tested algae showed large variations between seasons. Winter had both the highest median of $6.7 \%$ dry wt. and variability. This could be due to the higher concentrations of nitrate, nitrite and phosphate during this season which leads to increase in protein content. This observation is confirmed by the positive correlation of protein content with dissolved nitrate, nitrate and phosphate and negative correlation with temperature and salinity. Banerjee et al., 2009 found the same trend of protein among seasons and the active period of carbohydrate 
production matches with the decrease in protein content in seaweeds and vice versa.

The total lipids content of the selected seaweeds was fluctuated among sites. Site I had both the highest median (1.3\%) and variability. This associated with the presence of the green seaweed Caulerpa racemosa which had the highest content of lipids at this site. While, site II had both the lowest median $(0.74 \%$ dry wt.) and variability as a result of absence of the green seaweed $C$. racemosa at this site. This green seaweed was also present at site III and it responsible for outliers of $4.5 \%$ dry wt. and $3.9 \%$ dry wt. On the other hand, there were slight fluctuations in the total lipid content throughout the year. Summer and autumn had the same median (0.89\% dry wt.) and highest variability. Mwalugha et al., 2015 suggested the environmental conditions that favor photosynthesis (during summer and autumn) favored crude fat synthesis.

Moisture content of the investigated algae was not varied among sites While, it was fluctuated between seasons. The highest median was $8.6 \%$ dry wt. during summer followed by autumn $8.5 \%$ dry wt., while the lowest median was $4.6 \%$ dry wt. during spring. Variations in moisture among seasons may be due to changing in environmental parameters (Carrillo-Domínguez et al., 2012).

Ash content of the investigated seaweeds was not varied among sites and seasons. Nisizawa, 2006 reported that, marine seaweeds absorb minerals in their ionic form from seawater, but they shall depend upon several factors including concentration in the waters, growth stage of the algae and competition among the ions for uptake by the seaweeds. In the studied seaweeds, a negative correlation was found between ash content and carbohydrate $(r=-0.39, \mathrm{p}<0.05)$. This result is in accordance with Marinho-Soriano et al. (2006).

The total fibers of the studied seaweeds showed significant differences among sites and seasons. Site II had the highest variability followed by site III. This could be because of the highest cover of brown seaweeds; $S$. aquifolium and $P$. myrica which had the highest average of fiber at site II. On the other hand, the highest median was $42.5 \%$ dry wt. during winter, while the lowest was $33.1 \%$ dry wt. during summer and autumn. Siddique et al., 2013 reported that, the differences in a crude fiber of seaweeds can take place due to the differences in growth stages and photosynthetic activity among seaweed species 
and the seasonal variations occur due to changing in the environmental parameters that influence photosynthesis and uptake of nutrients.

\section{Conclusion}

In the light of previous findings, this study showed that seasonal changes in the environmental conditions drove changes in nutritional composition of intended algae. The six studied seaweeds along the Egyptian Red Sea coast are considered as a good source of fiber, mineral, carbohydrates and protein. The nutritional values of these seaweeds were based on chemical analyses only. Biological evaluation using human and animal feeding studies would be required to establish the nutritional value of these seaweeds, particularly the in vivo carbohydrates and fibers digestibility.

\section{References}

Aguilera-Morales M., Casas-Valdez M., Carrillo-Domı'nguez S., Gonsa'lezAcosta B. and Pe'rez-Gil F. (2005).Chemical composition and microbiological assays of marine algae Enteromorpha sp. as a potential food source. Journal of Food Composition and Analysis. 18, 79-88.

Aleem, A.A. (1978). A preliminary list of algae from Sierra Leone. Bot. Mar. 21, 397-399.

AOAC (1990). Official methods of Analysis. $14^{\text {th }}$ ed. Association of Analytical chemists. Washington DC, USA.

AOAC (1995). Official methods of Analysis. $16^{\text {th }}$ Ed. Association of analytical chemists. Washington DC, USA.

AOAC (2000). Official methods of Analysis. $17^{\text {th }}$ Ed. Association of analytical chemists. Washington DC, USA. 
APHA (2005). Standard methods for the examination of water and wastewater. 21st Eds. Washington D.C. Armbrust, E.V., 2004. The genome of the diatom Thalassiosira pseudonana: ecology, evolution, and metabolism. Science. 306, 79-86.

Banerjee K., Ghosh R. Homechaudhuri S. and Mitra A. (2009).Seasonal variation in the biochemical composition of red seaweed (Catenella repens) from Gangetic delta, northeast coast of India. J. Earth Syst. Sci. 118, 497-505.

Carrillo-Domínguez, S., M.M. Casas-Valdéz, F. Ramos-Ramos, F. Pérez-Gil and I. Sánchez-Rodríguez. (2012). Algas marinas de Baja California Sur, México: Valor nutrimental. Arch. Latinoam. Nutr. 52, 400-405.

Coppejans, E., and Beeckman, T. (1990).Caulerpa (Chlorophyta, Caulerpales) from the Kenyan coast. Nova Hed. 50, 111-125.

Dawczynski, C., Schubert R and Jahreis G. (2007).Amino acids, fatty acids, and dietary fibre in edible seaweed products. Food Chem., 103, 891-899.

El Shoubaky, G. A. and Kaiser, M. A. (2014). Monitoring Spatial and Temporal Seaweeds Variation Using Remote Sensing Data in Al-Shoaiba Coast, Red Sea. British Journal of Environment \& Climate Change. 4(4), 409422.

El-Manawy, I.M., Hamdy A. A., El-Deek, M. S., and Mohammed, A. A. (2000). Seasonal variations in iodine content of some seaweeds from the great Bitter Lake, Egypt. Bull. Fac. Sci., Assiut Univ., 29, 199-209.

El-Manawy, I.M. (2001). Floristic composition and zonation of seaweeds on Zabargad coral reef (Red Sea, Egypt), Taeckolmia, 21 (1), 115-134.

El-Manawy, I. M. (2008). Evaluation of the nutritional composition of seven seaweeds from Egypt. Egyptian J of Biotechnology, 29: 39-47.

García-Casal, M.N., Pereira, A,C, Leets, I., Ramìrez, J., Quiroga, M.F. (2007). High iron content and bioavailability in humans from four species of marine algae. The Journal of Nutrition; 137, 2691-2695. 
Goecke, F., Hern’andez, V., Bittner, M., González, M., Becerra, J. and Silva, M. (2010). Fatty acid composition of three species of Codium (Bryopsidales, Chlorophyta) in Chile. Revista de Biologia Marinay Oceanografia, 45 (2), 325-330.

Harley, C. D. G., Anderson, K. M., Demes, K. W., Jorve, J. P., Kordas, R. L., Coyle, T. A. and Graham, M. H. (2012). Effects of Climate Change on Global Seaweed Communities. Journal of Phycology, 48(5), 1064-1078.

Hedge, J.E. and Hofreiter, B.T. (1962). Carbohydrate Chemistry (Whistler R. L. and Be Miller J. N. ed.), Academic Press New York.

Ibraheem, B. M., Alharbi, R. M, Abdel-Raouf, N. and Al-Enazi, N. M. (2014).Contributions to the study of the marine algae inhabiting Umluj Seashore, Red Sea. Beni -suef university journal of basic and applied sciences, 3, 278-285.

Kamal H. (2014). Seaweed as health status indicator for Ghardaqa coral reef. Master science thesis. Environmental science department, faculty of science, Suez Canal University.

Kim, Se-Kwon (Ed). (2012). Handbook of Marine Macroalgae: Biotechnology and Applied Phycology. Hoboken, NJ: John Wiley \& Sons.

Lowry, O. H., Rosebrough, N.N., Farr, A.L. and Randall, R.Y. (1951). Protein measurement with the Folin Phenol reagent. Journal of Biological Chemistry.193, 265- 275.

Márcia de Pádua, P., Fontoura, S.G. and Mathias, A.L. (2004). Chemical composition of Ulvaria oxysperma (Kützing) bliding, Ulva lactuca (Linnaeus) and Ulva fasciata (Delile) Braz. Arch. Biol. Technol., 47, 4955.

Marinho-Soriano E., Fonseca P.C., Carneiro M.A.A and Moreira W.S.C. (2006). Seasonal variation in the chemical composition of two tropical seaweeds. Bioresource Technology 97, 2402-2406.

Moubayed, N. M. S., Al Houri, H. J., Al Khulaifi, M. M., and Al Farraj, D. A., (2017). Antimicrobial, antioxidant properties and chemical composition of seaweeds collected from Saudi Arabia (Red Sea and Arabian Gulf). Saudi Journal of Biological Sciences. 24, 162-169. 
Mwalugha, H. M., Wakibia, J. G., Kenji, G. M. and Mwasaru, A. M. (2015). Chemical Composition of Common Seaweeds from the Kenya Coast. Journal of Food Research; 4,(6) 28-38.

Nisizawa, K., (2006). Seaweeds Kaiso Bountiful Harvest from the Sea. In Seaweed Resources of the World (Critchley, A. T., Ohno, M., Largo, D.B. editors).Japan International Cooperation Agency, Yokosuka.

Ortiz, J., Romero, N., Robert, P. Araya, J. Lopez-Hernández, J. Bozzo, C., Navarrete, E., Osorio, A. and Riosa, A. (2006). Dietary fiber, amino acid, fatty acid and tocopherol contents of the edible seaweeds Ulva lactuca and Durvillaea Antarctica. Food Chem., 99, 98-104.

Osman, N. A., El-Manawy, I. M. and Amin, A. S. (2011). Nutritional composition and mineral content of five macroalgae from Red Sea. Egyptian J. of Phycol. 12, 89-102.

Russell, G. and Fielding, A. H. (1981). Individuals, populations and communities, [in:] The biology of seaweeds, Lobban, C. S. and Wynne, M. J. (eds.), Blackwell Scientific Publications, Oxford, pp. 393-420.

Sahoo, D. (2001). Seaweeds of Indian coast. A.P.H. Publishing Corporation, New Delhi. 283 pp. 


\section{التغيرات المكانية والزمانية في التركيب الغذائي لبعض الأعشاب البحرية من البحر الأحمر ، مصر}

إسلام محمود المناوى' , محمد زين العابدين نصار ' و سارة حدى رشيدى '

$$
\text { ' قسم النبات - كلبة العلوم - جامعة قناة السوبس المعهد القومى لعلوم البحار والمصايد }
$$

تم تقييم الاختلافات المكانية والموسمية في التركيبة الغذائية لبعض الأعشاب البحرية السائدة في

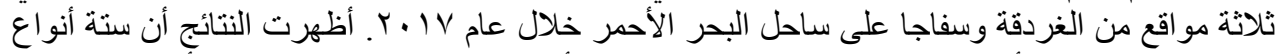



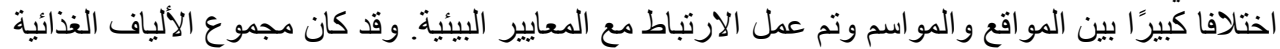

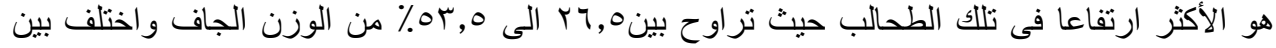

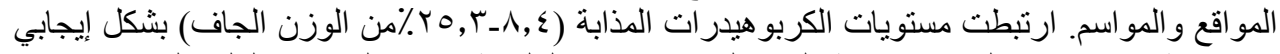

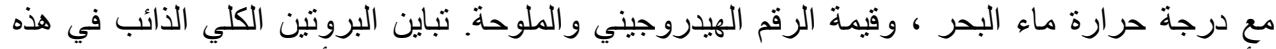

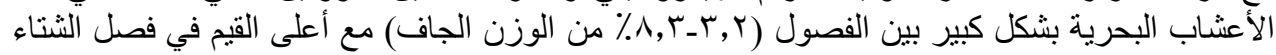

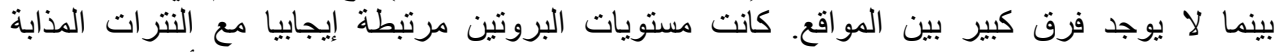

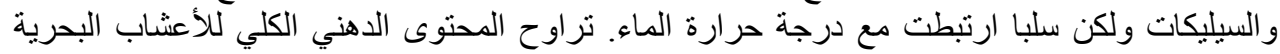

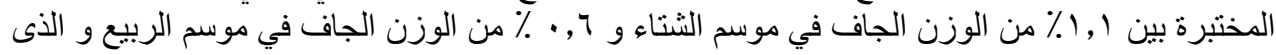

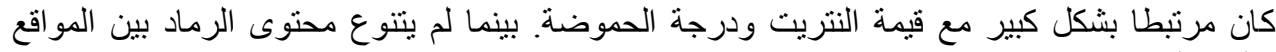

